\section{Os Grandes Avanços da Endocrinologia na Eva Genômica}

A CONCEITUADa Revista De eCONOmia The Economist definiu o Brasil como o país do futebol, do samba e da genômica, após a publicação do genoma do fitopatógeno, Xylella fastidiosa, realizada por uma rede de pesquisadores brasileiros que ganhou a capa da revista Nature e uma maior visibilidade da ciência brasileira no ano 2000. Confesso que, como representante da população feminina, fiquei surpresa pela ausência nesta lista de atributos brasileiros da decantada em verso e prosa "beleza da mulher brasileira", e exultei de contentamento com a inclusão da "poderosa" genômica. Recentes avanços da Ciência Brasileira nesta área incluíram o nosso país em um campo geralmente dominado pelas nações desenvolvidas e mergulhou a sociedade científica em um mar de orgulho e esperanças, de forma semelhante ao recente penta-campeonato.

Nesta Edição, os Arquivos Brasileiros de Endocrinologia \& Metabologia reservaram um espaço especial para temas diversos na área de biologia molecular aplicada na Endocrinologia, de forma a integrar o médico a esta rica fonte de novas informações. Os artigos foram preparados por pesquisadores brasileiros altamente qualificados, alguns deles residentes no exterior, e constituem revisões atualizadas de grande valor didático.

Inicialmente, os conhecimentos sobre a estrutura gênica de diversos hormônios, seus respectivos receptores e dos componentes da cascata de ativação intracelular foram fundamentais para os avanços da Endocrinologia Molecular. Posteriormente, a identificação de mutações inativadoras ou ativadoras de ocorrência espontânea, além da criação de mutações artificiais dirigidas a sítios específicos e à produção de modelos animais transgênicos, permitiram um enorme avanço na compreensão das ações hormonais, e nos mecanismos fisiopatogênicos de diversas doenças humanas. Nesta nova era caracterizada pela aplicação das técnicas de biologia molecular, tais como seqüenciamento e análise de expressão gênica, diversas síndromes de resistência hormonal e de hiperfunção endócrina tiveram seus mecanismos celulares revelados. Doenças como diabetes melitus, anomalias do desenvolvimento sexual e baixa estatura tiveram parte dos seus mecanismos moleculares identificados e novas classificações foram formuladas com esclarecimentos das formas previamente denominadas idiopáticas. Além disso, diversas síndromes novas, embora raras, foram identificadas e contribuíram ainda mais para a compreensão da fisiologia hormonal. A variabilidade étnica de diversas doenças foi também explicada pela identificação de fatores genéticos. O impacto destes conhecimentos se fez presente na conduta clínica, na investigação laboratorial e na descoberta de novas drogas.

No último congresso da Endocrine Society em São Francisco, em Junho de 2002, o principal foco foi o impacto do genoma humano na Endocrinologia e, mais uma vez, ficou evidente que os conhecimentos sobre o genoma afetaram de forma definitiva a Endocrinologia. Um dos principais frutos do Projeto Genoma Humano é a descoberta de milhões de editorial

\author{
Ana Claudia Latronico
}

Unidade de Endocrinologia do Desenvolvimento, Disciplina de Endocrinologia e Metabologia, Hospital das Clinicas da Faculdade de Medicina da Universidade de São Paulo, SP. 
variações na seqüência do DNA. A maioria destas variantes é constituída pela troca de um único nucleotídeo (single nucleotide polymorphisms: SNPS) cuja genotipagem abre um amplo campo de estudos envolvendo doenças complexas e poligênicas através de estudos populacionais, incluindo a resposta a drogas.

Os conceitos médicos atuais incluem a noção de que todas as doenças humanas têm virtualmente um componente genético, e que não há nenhum DNA humano perfeito. Estes fatos indicam o valor imensu- rável desta nova tecnologia que contempla o ideal universal da humanidade neste século XXI: longevidade aliada à saúde.

\section{Endereço para correspondência:}

Ana Claudia Latronico

Av. Dr. Enéas de Carvalho Aguiar, 155

Prédio dos Ambulatórios, $2^{\circ}$ andar, bloco 6

05403-900 São Paulo, SP

FAX: (01 1) 3083-0626

e.mail: anacl@usp.br 